\title{
Production of Biogas from Multiple Feedstocks and its Application as a Fuel for Spark Ignition Engines - A Review
}

\author{
M. Mohamed Musthafa ${ }^{1 \star}$
}

\author{
${ }^{1}$ School of Mechanical Engineering, SASTRA Deemed University, Thanjavur-613401, INDIA \\ *Corresponding Author: mohamedmustafa@mech.sastra.edu
}

Citation: Musthafa, M. M. (2020). Production of Biogas from Multiple Feedstocks and its Application as a Fuel for Spark Ignition Engines - A Review. European Journal of Sustainable Development Research, 4(3), em0120. https://doi.org/10.29333/ejosdr/7813

\section{ARTICLE INFO}

Received: 10 Oct. 2019

Revised: 6 Jan. 2020

Accepted: 6 Jan. 2020

\begin{abstract}
The passenger cars run by petrol are mostly used for transportation in India. The increases in fuel demand as the vehicles increases, high fuel cost due to price fixation daily and pollute the environment with their combustion products, engineers concern have to look an alternate fuel for petrol in Spark Ignition (SI) engine. Alternative fuels such as LPG (Liquefied Petroleum Gas), CNG (Compressed Natural Gas) are used in SI engines are current development. The use of biogas is also a better exchange for LPG and CNG fuel. Because biogas is easily producible, has a high octane number, lower emission level, wider flammability range, lower cost per energy unit of biogas, high self-ignition temperature and it also resists knocking, which is desirable in SI engines. Limited authors have attempted to use biogas as a substitute fuel for petrol in $\mathrm{SI}$ engine and dual fuel in Compression Ignition $(\mathrm{Cl})$ engine on their experimental studies. This paper reviews those studies and gives an observation for researcher's to make use of biogas as an alternative fuel for spark-ignition engines efficiently.
\end{abstract}

Keywords: alternate fuel, biogas, compression-ignition engine, dual fuel, spark-ignition engine

\section{INTRODUCTION}

The enormous growth in industries and an increase in population is the main reason for the heavy depletion of fossil fuel. Owing to the current energy scenario, the entire world is looking alternate to fossil fuels that should be renewable ones. Gaseous fuels are widely used nowadays because of their wide ignition limits and also have the capability to form a uniform mixture which reduces pollution. Various alternative gaseous fuels are compressed natural gas, liquefied petroleum gas, hydrogen, biogas, producer gas. Among the all renewable energy sources, biogas is particularly significant because of possibility of use in internal combustion engines (Mustafi et al., 2008), which are the main power source for transport sectors and also biogas is become more popular in rural areas for cooking and is produced from cow dung, other animal wastes and also from plant wastes by anaerobic decomposition. It is also known as gobar gas. Biogas is used as an alternative fuel in petrol engine and dual fuel in the diesel engine. Biogas is primarily composed of methane $\left(\mathrm{CH}_{4}\right)$, carbon dioxide $\left(\mathrm{CO}_{2}\right)$, hydrogen $\left(\mathrm{H}_{2}\right)$, nitrogen $\left(\mathrm{N}_{2}\right)$ and minute impurities like hydrogen sulphide $\left(\mathrm{H}_{2} \mathrm{~S}\right)$. Biogas can be subjected to clean by removal of impurities by scrubbing process. It is made up of twothird methane and remaining by carbon dioxide by volume. Biogas is safer in many aspects compared to other fuels. Ignition temperature for biogas is higher compared to gasoline and diesel fuel, which reduces ignition delay and makes it less hazardous. Biogas can be upgraded to synthetic gas by Removal of $\mathrm{CO}_{2}$ is necessary to increase the density and calorific value of the gas to meet quality (Qian et al., 2017). An attempt was made by a researcher to a covert diesel engine to SI engine fueled by biogas and an observed $35 \%$ and $40 \%$ less power compared to diesel and gasoline fuel respectively (Dobslaw et al., 2019). Inconsequent with another study was done by Neyeloff and Cunkel (1981) in a Cooperative Fuel Research (CFR) engine fuelled with simulated biogas in different compression ratios They have noted storing and transportation were main challenges for biogas. Thring (1985) concluded that biogas would be glowing appearance just where it is close to the production site. This review paper is covered the potential biogas production and its application as a fuel in IC engines. The objective of this review is to make a simple for the researcher to do future development.

\section{BIOGAS PRODUCTION}

Biogas is the product of fermentation of man and animals' biological activity waste products when bacteria degrade biological material in the absence of oxygen, in a process known as anaerobic digestion. Raw materials mostly used for biogas production 


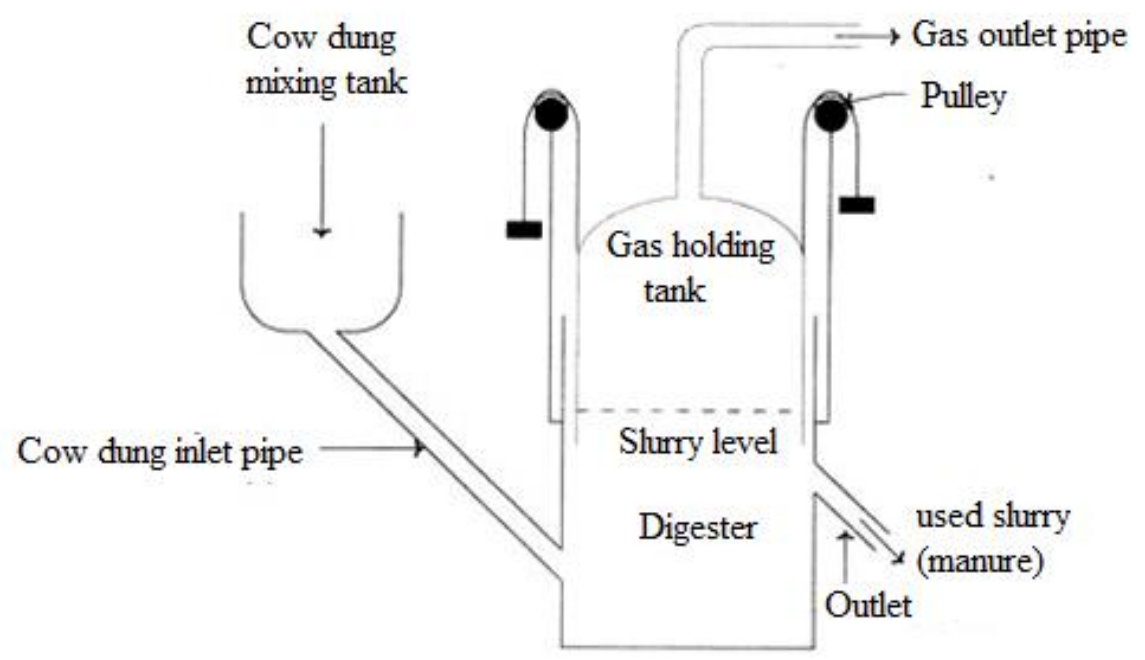

Figure 1. Schematic diagram of floating drum type plant for biogas production

Table 1. Biogas composition

\begin{tabular}{ccc}
\hline Composition & Molecular Formula & Percentage \\
\hline Methane & $\mathrm{CH}_{4}$ & $50-75$ \\
\hline Carbon dioxide & $\mathrm{CO}_{2}$ & $25-50$ \\
\hline Nitrogen & $\mathrm{N}_{2}$ & $0-10$ \\
\hline Hydrogen & $\mathrm{H}_{2}$ & $0-1$ \\
\hline Hydrogen sulphide & $\mathrm{H}_{2} \mathrm{~S}$ & $0-3$ \\
\hline
\end{tabular}

are cow dung, sewage, crop residues, vegetable wastes, poultry droppings and pig manure. Biogas is produced by hydrolysis, acidogenesis, acetogenesis, methanogenesis. Various types of biogas plants based on design are

- Fixed dome plant

- Floating drum plant

- Low cost polyethylene tube digester

- Baloon plants

- Horizontal plants

- Earth pit plants

- Ferrocement plants

Experimental purpose the floating drum type is most commonly used to produce biogas in India. The Floating drum type plant is shown in Figure 1.

It consists of airtight container made of steel or brick masonry is called a digester with inlet and outlet for raw material feeding and getting manure respectively. Another drum is called floating drum which floats over fixed digester employing rope and weight through the pulley. It has an opening at the top as a gas outlet. The ideal temperature for the production of biogas is $30^{\circ}$ to $40^{\circ} \mathrm{C}$ and the required $\mathrm{pH}$ will be 6 to 8 . Inhibitors can also be used to produce methane like ammonium sulfate. In case of cow dung as a feedstock for biogas production, cow dung is mixed with water in 3:1 ratio and fed to the digester through an inlet and set up is placed in an open atmosphere and exposed to sunlight. After two or three weeks, cow dung is digested to yield biogas. The biogas main constituent and their percentage are listed in Table 1. Some important thermodynamic properties of biogas are listed in Table 2. 
Table 2. Biogas Fuel Properties

\begin{tabular}{cc}
\hline Molecular Weight & $24-29$ \\
\hline Density $\left(\mathrm{kg} / \mathrm{L}, 15^{\circ} \mathrm{C}\right)$ & $0.96-1.17 \mathrm{~kg} / \mathrm{m}^{3}$ \\
\hline Specific Gravity $\left(15^{\circ} \mathrm{C}\right)$ & $0.94-0.98$ \\
\hline Boiling point & $300^{\circ} \mathrm{C}$ \\
\hline Specific Heat & $1.6 \mathrm{~kJ} / \mathrm{kg}-\mathrm{k}$ \\
\hline Individual Gas constant R & $0.518 \mathrm{~kJ} / \mathrm{kg} \mathrm{K}$ \\
\hline Latent Heat of Vaporization & $481 \mathrm{~kJ} / \mathrm{kg}$ \\
\hline Lower Heating Value & $21570 \mathrm{~kJ} / \mathrm{m}^{3}$ \\
\hline Higher heating value & $23000 \mathrm{~kJ} / \mathrm{m}^{3}$ \\
\hline Autoignition Temperature, & $600-650^{\circ} \mathrm{C}$ \\
\hline Octane Number & 130 \\
\hline Boiling point & $-161.5^{\circ} \mathrm{C}$
\end{tabular}

Table 3. Biogas as a fuel in dual fuel $\mathrm{Cl}$ engine

\begin{tabular}{|c|c|c|c|c|}
\hline \multicolumn{2}{|c|}{ INVESTIGATORS ENGINE SPECIFICATION } & \multicolumn{2}{|c|}{ BIOGAS PRODUCTION PERFORMANCE RESULTS } & \multirow[b]{2}{*}{$\begin{array}{l}\text { EMISSION RESULTS } \\
\text { y NOx emission reduced by } 2.6 \% \\
\text { and CO emission increased by } \\
3.3 \% \text { compared to diesel at full } \\
\text { load }\end{array}$} \\
\hline $\begin{array}{l}\text { Jagadish and } \\
\text { Gumtapure } \\
\text { (2019) }\end{array}$ & $\begin{array}{l}\text { Single cylinder, four-stroke } \\
\text { constant speed, direct } \\
\text { injection, water-cooled } \\
\text { diesel engine }\end{array}$ & $\begin{array}{l}\text { Simulated biogas } \\
\text { (different mixtures of } \\
\text { methane-enriched } \\
\text { biogas) }\end{array}$ & $\begin{array}{l}\text { The brake thermal efficiency is lower by } \\
2.43 \% \text { and the cylinder peak pressure is } \\
\text { higher by } 6.55 \% \text { for dual fuel mode } \\
\text { when compared with diesel mode. }\end{array}$ & \\
\hline $\begin{array}{l}\text { Ambarita et al. } \\
\text { (2017) }\end{array}$ & Tiger Diesel Engine R175 AN & $\begin{array}{l}\text { Simulated biogas } \\
\text { (mixing of natural gas } \\
\text { and } \mathrm{CO}_{2} \text { ) }\end{array}$ & $\begin{array}{l}\text { Output power and efficiency increases } \\
\text { with increasing engine speed and SFC } \\
\text { decrease. }\end{array}$ & $\begin{array}{l}\text { High } \mathbf{C O} \text { and } \mathbf{H C} \text { as the flow rate } \\
\text { of biogas increases. }\end{array}$ \\
\hline $\begin{array}{l}\text { Prajapati et al. } \\
\text { (2015) }\end{array}$ & $\sin$ & $\begin{array}{l}\text { Biodegradable } \\
\text { material }\end{array}$ & $\begin{array}{l}\text { BSFC is high with an increase in load } \\
\text { but TE decreases }\end{array}$ & $\begin{array}{l}\text { Emissions of } \mathrm{CO}_{2}, \mathrm{CO} \text { and } \mathrm{HC} \\
\text { increase with increasing load. }\end{array}$ \\
\hline Bora et al. (2014) & 3.5kW VCR diesel engine & Organic matter & $\begin{array}{l}\text { At a } 100 \% \text { load, BTE was } 20.04 \% \text { at } \\
\text { compression ratio is } 18\end{array}$ & $\begin{array}{l}\text { Reduction in } \mathbf{C O} \text { and } \mathbf{H C} \text { by } \\
26.22 \% \text { and } 41.97 \% \text { when } \mathrm{CR} \\
\text { increased from } 16 \text { to } 18 \text { but there } \\
\text { is an increase in } \mathrm{NO}_{x} \text { by } 66.65 \%\end{array}$ \\
\hline $\begin{array}{l}\text { Barik and } \\
\text { Murugan (2014) }\end{array}$ & $\begin{array}{l}\text { Single-cylinder direct } \\
\text { injection diesel engine }\end{array}$ & $\begin{array}{l}\text { Anaerobic digestion of } \\
\text { Pongamia pinnata } \\
\text { seed cakes }\end{array}$ & $\begin{array}{l}\text { The biogas flow rate of } 1.2 \mathrm{~kg} / \mathrm{h} \text { shows a } \\
\text { higher brake specific energy } \\
\text { consumption (BSEC) of } 51.8 \mathrm{MJ} / \mathrm{kWh} \text { at } \\
\text { higher energy share of } 60 \% \text {, at } 25 \% \text { load }\end{array}$ & $\begin{array}{l}\text { At full load, NO and smoke } \\
\text { emissions were found to be lower } \\
\text { by about } 34 \% \text { and } 14 \% \text { with long } \\
\text { ignition delay }\end{array}$ \\
\hline $\begin{array}{l}\text { Gomez-Montoya } \\
\text { et al. (2013) }\end{array}$ & $\begin{array}{l}\text { Two-cylinder diesel engine } \\
\text { coupled to an electric } \\
\text { generator }\end{array}$ & Organic waste & $\begin{array}{l}\text { Thermal energy increases up to } 16 \% \text { at } \\
\text { full load }\end{array}$ & $\begin{array}{l}\text { CO emission decreases up to } \\
13 \% \text { at full load }\end{array}$ \\
\hline $\begin{array}{l}\text { Gomez-Montoya } \\
\text { et al. (2010) }\end{array}$ & $\begin{array}{l}\text { 3.7kW Kirloskar diesel } \\
\text { engine }\end{array}$ & Orgar & $\begin{array}{l}\text { SFC decreases with an increase in } \\
\text { power and efficiency also increases }\end{array}$ & -- \\
\hline Bari (1996) & $\begin{array}{l}\text { Two-cylinder diesel engine } \\
16.8 \mathrm{~kW} \text { at } 1500 \mathrm{rpm}\end{array}$ & $\begin{array}{l}\text { Anaerobic } \\
\text { fermentation of } \\
\text { Biomass materials }\end{array}$ & $\begin{array}{l}\text { Percentage of } \mathrm{CO}_{2} \text { increases, power } \\
\text { increases and brake specific fuel } \\
\text { consumption (BSFC) decreases. }\end{array}$ & -- \\
\hline
\end{tabular}

\section{BIOGAS AS A FUEL FOR CI ENGINE}

Biogas cannot be used as a substitute fuel in diesel an account of high self-ignition temperature and high Octane number. But it can be used as a primary fuel in dual fuel mode in the modified existing engine and either diesel or biodiesel as pilot secondary fuel. Modification of diesel engine into a dual-fuel engine has the following advantages: Operation on diesel fuel alone is possible when biogas is not available. Any contribution of biogas from $0 \%$ to $85 \%$ can substitute a corresponding part of diesel fuel while performance remains as in 100\% diesel fuel operation (Van Ga et al., 2015). Various research on biogas as a fuel in the dual-fuel engine are listed in Table 3.

\section{BIOGAS AS A FUEL FOR SI ENGINE}

The use of biogas as an SI engine fuel offers several advantages. Biogas is a clean fuel causes clean combustion which results in low particulates and nitrogen oxides and reduced contamination of engine oil. The basic modification is required in $\mathrm{SI}$ engine is the provision of an air/gas mixer instead of the carburettor as the engine is designed to operate on an air/fuel mixture. From the previous studies conducted by Jeong et al. (2009); Arroyo et al. (2014); Kukoyi et al. (2016); Krishnaiah et al. (2017), it was noted that researchers have used both simulated biogas and direct biogas in their experimental studies. This review study has taken both cases and listed their result in Table $\mathbf{4}$ and $\mathbf{5}$. 
Table 4. Biogas blends as a fuel in SI engine

\begin{tabular}{|c|c|c|c|c|}
\hline INVESTIGATORS & ENGINE SPECIFICATION & BIOGAS PRODUCTION & PERFORMANCE RESULT & EMISSION RESULT \\
\hline $\begin{array}{l}\text { Park and Choi } \\
(2017)\end{array}$ & $\begin{array}{l}\text { Water-cooled turbocharged SI } \\
\text { engine }\end{array}$ & biogas with added hydrogen & $\begin{array}{l}\text { Maximum rise of BTE is } 3.2 \% \text { with } \\
\text { boost pressure for Air fuel ratio } 1.5\end{array}$ & $\begin{array}{l}\text { NOx emission got reduced with } \\
\text { boost pressure }\end{array}$ \\
\hline $\begin{array}{l}\text { Ayade and Latey } \\
(2016)\end{array}$ & 4 cylinder SI engine & $\begin{array}{l}\text { Cowdung and leaves with } \\
\text { petrol of } 60 \%, 80 \% \text { and } 90 \%\end{array}$ & $\begin{array}{l}\text { B40 obtained maximum results in } \\
\text { bsfc by } 12 \% \text { and BTE by } 17 \%\end{array}$ & $\begin{array}{l}\mathrm{CO} \text { and } \mathrm{HC} \text { emission increases as } \\
\text { gas substitution increases }\end{array}$ \\
\hline Singh (2016) & 4 stroke $\mathrm{SI}$ engine & $\begin{array}{l}\text { Biogas from Organic matter } \\
\text { with hydrogen }\end{array}$ & $\begin{array}{l}\text { BTE increases by } 20 \% \text { and bsfc } \\
\text { decrease by } 14 \% \text { with increasing } \\
\text { hydrogen }\end{array}$ & $\begin{array}{l}\mathrm{CO} \text { and } \mathrm{HC} \text { level decreases by } 80 \% \\
\text { and } 30 \% \text { and } \mathrm{NO}_{x} \text { increased by } 13 \% \\
\text { with hydrogen addition }\end{array}$ \\
\hline $\begin{array}{l}\text { Pandya et al. } \\
(2016)\end{array}$ & $\begin{array}{l}\text { 7.5 HP single cylinder Kirloscar } \\
\text { engine }\end{array}$ & Methane enriched by biogas & $\begin{array}{l}\text { Bsfc, ME is higher than petrol but BTE } \\
\text { was found to be low }\end{array}$ & \\
\hline $\begin{array}{l}\text { Juntarakod } \\
(2016)\end{array}$ & 3.5KW SI engine & Biogas and petrol & -- & $\begin{array}{l}\text { Hydrogen substitution causes an } \\
\text { increase in } \mathrm{H}_{2} \text { results in higher } \mathrm{NO}_{2} \\
\text { emission in lean combustion }\end{array}$ \\
\hline $\begin{array}{l}\text { Gohil } \\
\text { Bhavdipsinh et } \\
\text { al. (2016) } \\
\end{array}$ & 4 stroke SI engine & $\begin{array}{l}\text { Biogas with methanol blend } \\
\text { from } 0 / 20 / 50 \%\end{array}$ & $\begin{array}{l}\text { Brake torque, BP, BTE and volumetric } \\
\text { efficiency increases with increasing } \\
\text { methanol but bsfc decreases }\end{array}$ & \\
\hline $\begin{array}{l}\text { Awogbemi et al. } \\
(2015)\end{array}$ & 5 HP single cylinder SI engine & $\begin{array}{l}\text { Cowdung seeded with rice } \\
\text { husk and banana peel with } \\
\text { petrol }\end{array}$ & $\begin{array}{l}\text { The high torque of } 8.7 \mathrm{Nm} \text { for biogas } \\
\text { petrol blend at speed of } 3500 \mathrm{rpm} \text { and } \\
\text { BP of } 311.58 \mathrm{~kW} \text {. Mechanical } \\
\text { efficiency increases sharply between } \\
1000-1500 \mathrm{rpm} \text { and gently after that }\end{array}$ & \\
\hline Chen et al. (2012) & $\begin{array}{l}\text { Single-cylinder HONDA GX340 } \\
\text { engine }\end{array}$ & $\begin{array}{l}\text { Biomass with hydrogen and } \\
\mathrm{CO} \text { blended and diluted by } \\
\mathrm{CO}_{2}\end{array}$ & $\begin{array}{l}\text { BMEP and BTE increases with the } \\
\text { hydrogen addition }\end{array}$ & $\begin{array}{l}\text { NOx and CO emission reduces with } \\
\text { the increase of hydrogen } \\
\text { concentration }\end{array}$ \\
\hline Park et al. (2011) & $\begin{array}{l}\text { Constant speed } 6 \text { cylinder SI } \\
\text { engine }\end{array}$ & biogas with added hydrogen & $\begin{array}{l}\text { Maximum TE reaches at } 31.1 \% \text { at } 80 \% \\
\mathrm{~N}_{2} \text { dilution }\end{array}$ & $\begin{array}{l}\text { Increased } \mathrm{N}_{2} \text { dilution decreases } \\
\text { NOx level }\end{array}$ \\
\hline $\begin{array}{l}\text { Porpatham et al. } \\
\text { (2007) }\end{array}$ & $\begin{array}{l}\text { Single-cylinder constant speed } \\
\text { SI engine }\end{array}$ & $\begin{array}{l}\text { Cowdung with hydrogen } \\
\text { addition from } 5 \% \text { to } 15 \%\end{array}$ & $\begin{array}{l}\text { Improvement in TE and power output } \\
\text { with very lean mixtures and hydrogen } \\
\text { concentration of } 15 \%\end{array}$ & $\begin{array}{l}\text { HC emissions drop to } 660 \mathrm{ppm} \text { with } \\
10 \% \text { hydrogen addition and no } \\
\text { change in NO level. }\end{array}$ \\
\hline
\end{tabular}

Table 5. Biogas as fuel for SI engine INVESTIGATORS ENGINE SPECIFICATIONS

Hotta et al. (2019) Single cylinder, variable speed Raw biogas (1450-1700 rpm) spark ignition engine.

engine.
ent




\section{CONCLUSIONS}

From the comprehensive review study in various authors findings on biogas as a fuel in the IC engine, the review study concludes the following

- The production of biogas from various feedstock is feasible and its composition and properties are pertinent for substitute fuel in IC engines.

- The performance of diesel engines in dual fuel mode of either diesel or biodiesel and biogas is almost equal to diesel fuel operation.

- The emission characteristics of biogas fuelled SI engine are found relatively lower in particulates, carbon dioxide and nitrogen oxides emissions

- Biogas is a very efficient, sustainable and environmental friendly fuel which helps to reduce dependence on conventional fossil fuels and the management of waste,

Finally, biogas may be recommended as an alternative fuel in $\mathrm{Cl}$ engine.

\section{Suggestion for Future Development}

- For the long-run operation of $\mathrm{Cl}$ engine running on biogas fuel require the following attentions

- Developing the low cost biogas purification and upgrading technologies

- During the biogas simulation, it can be enhanced by methane enrichment or the addition of hydrogen to improve its flame quality.

\section{REFERENCES}

Ambarita, H. Sinulingga, E. P. Nasution, M. K. M. and Kawai, H. (2017). Performance and Emissions of a Small Compression Ignition Engine Run on Dual-fuel Mode (Diesel-Raw biogas). IOP Conference Series: Materials Science and Engineering 180. https://doi.org/10.1088/1757-899X/180/1/012025

Arroyo, J., Morena, F., Munoz, M. and Bernal, N. (2014). Combustion behavior of a spark ignition engine fueled with synthetic gases derived from biogas. Fuel, 117(Part A), 50-58. https://doi.org/10.1016/j.fuel.2013.09.055

Awogbemi, Omojola, A., Adeyemo, S. and Babatunde. (2015). Development and Testing of Biogas-Petrol Blend as an Alternative Fuel for Spark Ignition Engine. International Journal of Scientific \& Technology Research, 4(09), 179-186.

Ayade, M. and Latey, A. A. (2016). Performance and emission characteristics of biogas -petrol dual fuel in SI engine. International Journal of Mechanical Engineering and Technology, 7(2),45-54.

Bari, S. (1996). Effect of carbon dioxide on the performance of biogas/diesel dual-fuel engine. WREC, $1007-1010$. https://doi.org/10.1016/0960-1481(96)88450-3

Barik, D. and Murugan, S. (2014). Simultaneous reduction of NOx and smoke in a dual fuel DI diesel engine. Energy Conversion and Management, 84, 217-226. https://doi.org/10.1016/j.enconman.2014.04.042

Bora, B. J., Saha, U. K., Chatterjee, S. and Veer, V. (2014). Effect of compression ratio on performance, combustion and emission characteristics of a dual fuel diesel engine run on raw biogas. Energy Conversion and Management, 87, $1000-1009$. https://doi.org/10.1016/j.enconman.2014.07.080

Chen, L., Shiga, S. and Araki, M. (2012). Combustion characteristics of an SI engine fueled with H2-CO blended fuel and diluted by CO2. International Journal of hydrogen energy, 37, 14632-14639. https://doi.org/10.1016/j.ijhydene.2012.07.048

Dobslaw, D., Engesser, K.-H., Störk, H. and Gerl, T. (2019). Low-cost process for emission abatement of Biogas, internal combustion engines. Journal of Cleaner Production, 227, 1079-1092. https://doi.org/10.1016/j.jclepro.2019.04.258

Gohil Bhavdipsinh, J., Gohil Virpalsinh, B., Rana Manan, A., Pinkesh, G. and Sompura, M. (2016). Performance Evaluation of Methanol Blend Fuel in SI Engine. International Journal of Science and Research, 5(4), 396-399. https://doi.org/10.21275/v5i4.nov162561

Gomez-Montoya, J.-P., Cacua-Madero, K.-P., Iral-Galeano, L., Prajapati, A. K., Randa, R. and Parmar, N. (2015). Experimental study on utilization of biogas in IC engine. International Journal of Engineering Sciences and Research Technology, 827-836.

Hotta, S. K., Sahoo, N. and Mohanty, K. (2019) Comparative assessment of a spark ignition engine fueled with gasoline and raw biogas. Renewable Energy, 134, 1307-1319. https://doi.org/10.1016/j.renene.2018.09.049

Huang, J. and Crookes, R. J. (1998). Assessment of simulated biogas as a fuel for the spark ignition engine. Fuel, 77(15), $1793-1801$. https://doi.org/10.1016/S0016-2361(98)00114-8

Jagadish, C. and Veershetty, G. (2019). Experimental Studies of Biogas in a Single Cylinder Diesel Engine by Dual Fuel Mode of Operation. Applied Mechanics and Materials, 895, 109-114. https://doi.org/10.4028/www.scientific.net/AMM.895.109

Jeong, C., Kim, T., Lee, K., Song, S. and Chun, K. M. (2009) Generating efficiency and emissions of a spark-ignition gas engine generator fuelled with biogas-hydrogen blends. International Journal of hydrogen energy, 34, 9620-9627. https://doi.org/10.1016/j.ijhydene.2009.09.099 
Joshi, A. B., Umrigar, P. B., Patel, A. B. and Patel, K. A. (2015). Using Biogas in SI Engine by Changing Ignition Parameter and Compression Ratio. International Journal for Scientific Research \& Development, 3(02), 751-756.

Juntarakod, P. (2016). Effect of Equivalence Ratio on Composition and performance of Biogas and Gasoline Exhaust from Spark Ignition Engine by Mathematical Modeling. MATEC Web of Conferences 82. https://doi.org/10.1051/matecconf/20168201014

Kim, Y., Kawahara, N., Tsuboi, K. and Tomita, E. (2017). Combustion characteristics and NOX emissions of biogas fuels with various $\mathrm{CO} 2$ contents in a micro co-generation spark-ignition engine. Energy Conversion and Management, 149, $1096-1108$. https://doi.org/10.1016/j.apenergy.2016.08.152

Kimura, S., Akimoto, R., Gonzalez Palencia, J. C., Araki, M. and Shinga, S. (2015). Operation Characteristics with a Real Biogas by Using an SI Gas Engine Power Generation System. Journal of the Japan Institute of Energy, 94(6), 594-600. https://doi.org/10.3775/jie.94.594

Krishnaiah, R., Mathew, S., Bhasker, P. and Porpatham, E. (2017). Gaseous alternative fuels for Spark Ignition Engines-A technical review. Journal of Chemical and Pharmaceutical Sciences, 10(1), 93-99.

Kukoyi, T. O., Muzenda, E., Akinlabi, E. T., Mashamba, A., Mbohwa, C. and Mahlatsi, T. (2016). Biogas Use as Fuel in Spark Ignition Engines. IEEE. 1064. https://doi.org/10.1109/IEEM.2016.7798041

Mustafi, N. N., Raine, R. R. and Bansal, P. K. (2008). The Use of Biogas in Internal Combustion Engines: A Review. ICES 2006-1306, 225-234.

Neyeloff, S. and Cunkel, W. W. (1981). Performance of a CFR engine burning simulated anaerobic digester's gas. ASAE Publication 2, 324-329.

Nunes de Faria, M. M., Vargas Machuca Bueno, J. P., Elmassalami Ayad, S. M. M., Pereira Belchior, C. R. (2017). Thermodynamic simulation model for predicting the performance of spark ignition engines using biogas as fuel. Energy Conversion and Management, 149, 1096-1108. https://doi.org/10.1016/j.enconman.2017.06.045

Pandya, C. B., Shah, D. R., Patel, T. M. and Rathod, G. P. (2016). Performance Analysis of Enriched Biogas Fuelled Stationary Single Cylinder SI Engine. IOSR Journal of Mechanical and Civil Engineering, 13(2), 21-27.

Park, C., Park, S., Lee, Y., Kim, C., Lee, S., et al. (2011) Performance Evaluation of Methanol Blend Fuel in SI Engine by low calorific biogas blended with hydrogen. International Journal of hydrogen energy, 36, 10080-10088. https://doi.org/10.1016/j.ijhydene.2011.05.018

Park, J. and Choi, J. (2017). A numerical investigation of lean operation characteristics of spark ignition gas engine fueled with biogas and added hydrogen under various boost pressures. Applied Thermal Engineering, 117, $225-234$. https://doi.org/10.1016/j.applthermaleng.2017.01.115

Pohare, J., Pandey, K. C. and Mahalle, D. M. (2010). Improve the operation of IC engine with $100 \%$ biogas as fuel. Engineering and Technology in India, 1(2), 56-60.

Porpatham, E., Ramesh, A. and Nagalingam, B. (2007). Effect of hydrogen addition on the performance of a biogas fuelled spark ignition engine. International Journal of Hydrogen Energy, 32, 2057-2065. https://doi.org/10.1016/j.ijhydene.2006.09.001

Porpatham, E., Ramesh, A. and Nagalingam, B. (2012). Effect of compression ratio on the performance and combustion of a biogas fuelled spark ignition engine. Fuel, 95, 247-256. https://doi.org/10.1016/j.fuel.2011.10.059

Porpatham, E., Ramesh, A. and Nagalingam, B. (2013). Effect of swirl on the performance and combustion of a biogas fuelled spark ignition engine. Energy Conversion and Management, 76, 463-471. https://doi.org/10.1016/j.enconman.2013.07.071

Prajapati, A. K., Randa, R. and Parmar, N. (2015). Experimental Study on Utilization of Biogas in IC Engine. International Journal of Engineering Sciences \& Research Technology, 4(8), 827-835.

Prakash, J., Ranjan, C., Dhiman, S. K. and Kumar, A. (2016). Performance study of four stroke S.I. engine using upgraded biogas fuel. Applied Science Innovations Research Article, 8(3), 74-85.

Przybyla, G., Szlek, A. and Ziolkowski, L. (2013). Assessment of the Performance of a Small Capacity SI Engine Fuelled with Model Lean Mixture of Biogas. International Journal of Thermodynamics, 16(4), 179-188. https://doi.org/10.5541/ijot.470

Qian, Y., Sun, S., Ju, D., Shan, X. and Lu, X. (2017). Review of the state-of-the-art of biogas combustion mechanisms and applications in internal combustion engines. Renewable and Sustainable Energy Reviews, 69, 50-58. https://doi.org/10.1016/j.rser.2016.11.059

Samanta, A., Das, S. and Roy, P. C. (2016). Performance analysis of a biogas engine. International Journal of Research in Engineering and Technology, 5(01), 67-71. https://doi.org/10.15623/ijret.2016.0513012

Singh, S. (2016). Performance Analysis of (Hydrogen+Biogas) as Fuel for SI Engine. Imperial Journal of Interdisciplinary Research, 2(4), 15-21.

Thring, R. H. (1985). Alternative fuels for spark-ignition engines. SAE Paper no 831685.

Van Ga, B., Viet Hai, N., Minh Tu, B. T. and Van Hung, B. (2015). Utilization of Poor Biogas as Fuel for Hybrid Biogas-Diesel Dual Fuel Stationary Engine. International Journal of Renewable Energy Research, 5(4), 1007-1015.

Zhang, Y., Zhu, M., Zhang, Z. and Zhang, D. (2016). Combustion and Emission Characteristics of a Spark Ignition Engine Fuelled with Biogas from Two-Phase Anaerobic Digestion (T-PAD). International Conference on Applied Energy, $137-142$. https://doi.org/10.1016/j.egypro.2017.03.292 